\title{
RANDOMLY DIRECTED AND LIGHT WINDS EXACERBATE THE EMERGENCE OF LARGE-SCALE CYANOBACTERIAL BLOOM AREAS IN LAKE TAIHU, CHINA
}

\author{
XU, D. ${ }^{1}-$ CHEN, H. ${ }^{2,3^{*}}$ \\ ${ }^{1}$ College of Water Conservancy and Hydropower Engineering, Hohai University, No. 1 Xikang \\ Road, Nanjing 210098, China \\ ${ }^{2}$ School of Materials Engineering (School of Environmental Engineering), Changzhou Institute \\ of Industry Technology, Changzhou 213164, China \\ ${ }^{3}$ College of Environment, Hohai University, No. 1 Xikang Road, Nanjing 210098, China \\ *Corresponding author \\ e-mail: huaiminchen@163.com \\ (Received $31^{\text {st }}$ Jan 2020; accepted $22^{\text {nd }}$ May 2020)
}

\begin{abstract}
The global warming, decline in wind speed and extreme rainfall have been documented to promote the expansion of bloom area. However, few studies focus on the effect of wind direction on bloom area. The monthly data between May and September from 2011 to 2018 were collected to analyze the relationship between environmental factors and bloom area. Pearson correlation analysis indicated that bloom area was negatively correlated with monthly proportion of consecutive unidirectional wind days $\left(P_{C U W D}\right)$ but positively correlated with chlorophyll a $(\mathrm{Chl}-\mathrm{a})$. During the whole studied period, wind speeds were lower than $3.1 \mathrm{~m} / \mathrm{s}$ and Chl-a concentrations were higher than $20 \mu \mathrm{g} / \mathrm{L}$ in all months. In this case, the sufficient Microcystis biomass could aggregate into large-scale bloom area only by vertical floating. This could explain why no significant relationship between wind speed and bloom area was found in our study. Except for August, wind speed declined each month which promoted the increase of total phosphorus (TP) and Chl-a concentrations. The low value of $P_{C U W D}$ insufficiently transported cyanobacterial patches from other zones to accumulate with the existing cyanobacterial patches in the downwind area of the lake into dense and small-scale surface scum. In May and June, the decreased $P_{C U W D}$ was conducive to maintain a large-scale bloom area.
\end{abstract}

Keywords: climate change, environmental factors, wind direction, vertical aggregation, horizontal transportation

\section{Introduction}

The excessive releases of nitrogen and phosphorus have accelerated eutrophication in lakes and reservoirs, which has induced frequent occurrence of cyanobacterial blooms (Xiao et al., 2018). Cyanobacterial blooms may initiate a chain of serious environmental and ecological events, resulting in blockage of drinking-water supply systems, reduction of water clarity and production of unpleasant odors, etc. (Qin et al., 2010; Zhang et al., 2011). Moreover, some species of cyanobacteria would produce a variety of potent toxins and pose severe risks to human health (Funari and Testai, 2008). Bloom area is one of the common indicators used in water resource management to rank the alert levels of cyanobacterial blooms ( $\mathrm{Li}$ et al., 2016). In 2017, a large-scale bloom area of $1403 \mathrm{~km}^{2}$ occurred in Lake Taihu, which has attracted much attention. However, our knowledge on the formation of large-scale bloom areas is still limited.

Sufficient cyanobacterial biomass is a prerequisite for the formation of cyanobacteria bloom (Reynolds, 2006). Many previous studies have revealed that nutrients play a 
leading role in rapid cyanobacterial growth and domination in freshwater ecosystem (Hecky and Kilham, 1988). In addition, climate change is expected to affect the cyanobacterial development throughout their entire annual cycle in both direct and indirect ways (Jeppesen et al., 2014). The warming trend of air temperature affects cyanobacterial biomass by prolonging the duration of the growing season globally (O'Reilly et al., 2015). The change of rainfall intensity and frequency also affects cyanobacterial biomass due to a large amount of nutrients input into water bodies by flushing (Michalak et al., 2013; Reichwaldt and Ghadouani, 2012).

Wind-induced turbulence directly determines the formation and disappearance of cyanobacterial blooms (Wu et al., 2013; Zhu et al., 2014b). Numerous field studies have reported that cyanobacterial blooms in lakes and reservoirs disappear when wind speeds exceeding the critical value, namely 3-4 m/s (Cao et al., 2006; Ma et al., 2015; MorenoOstos et al., 2008). When the wind speeds drop below the critical value, cyanobacteria would overcome the weak mixing and float up to the surface to form the blooms. In recent years, there are reported studies showing the global warming could cause the decline of wind speeds (Deng et al., 2018; McVicar et al., 2012). Meanwhile, the decrease of wind speeds could promote the annual mean bloom area in lakes as confirmed by other scholars (Deng et al., 2018; Wu et al., 2015).

Aforementioned researches mainly focused on the effects of climate-induced temperature and precipitation changes on the growth of cyanobacterial biomass, and the decreases of wind speeds on the expansion of bloom areas. In addition to wind speed, wind direction is also an important indicator of wind field. Present studies regarding wind direction are mainly focused on how does it affect the horizontal distributions of cyanobacterial blooms in lakes (Cyr, 2017; Deng et al., 2016). These studies only indicated that cyanobacterial blooms tend to occur in downwind areas of lakes (George and Edwards, 1976). Little attention has been paid to the effect of wind direction on bloom areas.

The cyanobacterial biomass in summer and autumn is much higher than that in spring and winter, which is conducive to the emergence of larger-scale and more serious cyanobacterial blooms (Deng et al., 2014; Shi et al., 2019). The mature blooming stage is usually from May to September in Lake Taihu, when the temperature reaches the optimum temperature for the growth of Microcystis (Feng et al., 2018). Elucidation of the responses of bloom area to environmental changes during this period can improve our understanding for better controlling water blooms. In this study, we collected a 8year data series between May and September from Lake Taihu to examine: (1) temporal variations in the meteorological data, nutrient factors and cyanobacterial biomass, (2) the primary factors affecting cyanobacterial bloom area, and (3) the effect of wind direction on large-scale bloom area.

\section{Materials and methods}

\section{Study area}

Lake Taihu is a large shallow freshwater lake, which is situated in the southeastern part of Yangtze River Delta in China (30 $55^{\prime} 40^{\prime \prime}-31^{\circ} 32^{\prime} 58^{\prime \prime} \mathrm{N}$; 119 $52^{\prime} 32^{\prime \prime}-$ $\left.120^{\circ} 36^{\prime} 10^{\prime \prime} \mathrm{E}\right)$. The lake is $68.5 \mathrm{~km}$ long from north to south and $34 \mathrm{~km}$ wide from east to west with a surface area of $2338 \mathrm{~km}^{2}$ (Han et al., 2015; Havens et al., 2016). Its average depth is $1.9 \mathrm{~m}$ with a maximum depth of $2.6 \mathrm{~m}$. The water quality of Lake Taihu has been seriously affected by eutrophication and surficial cyanobacterial blooms 
due to the large amount of pollutants input from industry, agriculture and tourism activities over the past 3 decades ( $\mathrm{Li}$ et al., 2014; Wang et al., 2016). It is well-known that Lake Taihu was subjected to a severe cyanobacterial bloom in May 2007, depriving more than 2 million people of drinking water for several days.

\section{Data collection}

Meteorological data between May and September from 2011 to 2018 were obtained from Wuxi weather station of National Meteorological Information Center (http://data.cma.cn). The monthly meteorological data were calculated form the daily records of air temperature $\left(\mathrm{T}_{\text {air }}\right)$, precipitation $(\mathrm{P})$ and wind speed $(\mathrm{WS})$.

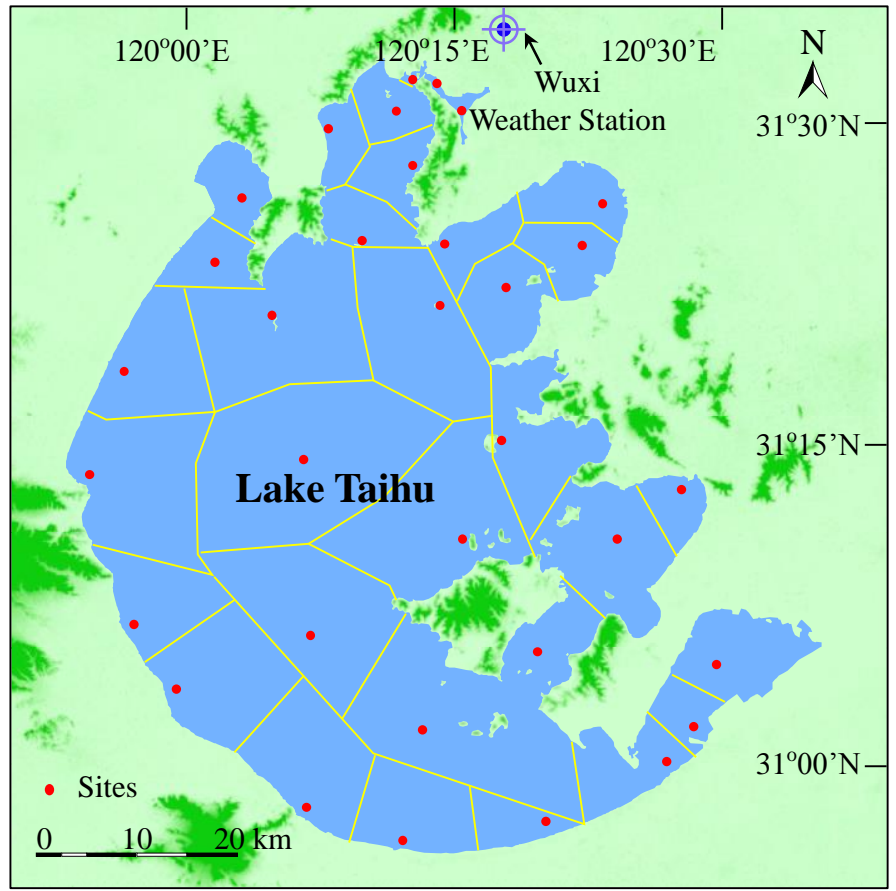

Figure 1. Location of sampling sites and Wuxi weather station in Lake Taihu

Consecutive unidirectional winds days $(C U W D)$ indicates a continuous period that the difference between the maximum and minimum wind direction is less than $45^{\circ}$, which is calculated as follows $(E q .1)$ :

$$
C U W D=\operatorname{Count}(x i: x j) \text { If } \operatorname{Max}(x i: x j)-\operatorname{Min}(x i: x j) \leq 45^{\circ} \text { and } j-i \geq 3
$$

where $x_{i}$ and $x_{j}$ are the values of wind direction at day $i$ and $j$, respectively. In order to measure the length of $C U W D$ in a month, the following formula (Eq. 2) is given to calculate the monthly proportion of $C U W D\left(P_{C U W D}\right)$ :

$$
P_{C U W D}=\frac{\sum\left(C U W D_{k}-2\right)}{T} k=1,2, \ldots, n
$$

where $\mathrm{T}$ is the total days in each month. 
Monthly total nitrogen (TN), total phosphorus (TP), and chlorophyll a (Chl-a) concentration from 33 sampling sites of Lake Taihu were collected from Taihu Basin Authority of Ministry of Water Resources (http://www.tba.gov.cn/) between May and September from 2011 to 2018. The entire lake was divided into 33 sections based on sampling sites using the Tyson polygon method (Fig. 1). Then, a weight factor was calculated as the area of each polygon relative to the total area of the lake for each sampling site. Finally, the summation of concentration multiplied with weight factor in each site was defined as monthly concentration of entire lake, in order to address spatial heterogeneity.

Bloom areas were derived from remote sensing images from May to September during 2011-2018, which were obtained from the Lake-Watershed Science Data Center, National Earth System Science Data Sharing Infrastructure, National Science \& Technology Infrastructure of China (http://lake.geodata.cn). Monthly bloom area is calculated by the average of 5 images selected at 5-day intervals each month. If there was cloudy or rainy weather on that day, the photos before or after a day were used.

\section{Data analysis}

Principal components analysis (PCA) were carried out to identify the the role of the various environmental factors contributing to the bloom area. The principal components (PCs) were extracted for eigenvalues that were $>1$. The Kaiser-Meyer-Olkin (KMO) and Bartlett's test were introduced to evaluate the validity of PCA, and a $>0.5$ of KMO and significant Bartlett's test were requisite before the PCA. The relationships of monthly bloom areas with environmental factors were analyzed by Pearson correlation coefficient. All statistical analysis were performed by SPSS 19.0 software (IBM, Armonk, NY, USA).

\section{Results}

\section{Monthly variations in meteorological data}

The temporal variations of meteorological factors in the Lake Taihu from 2011 to 2018 are presented in Figure 2. During the whole studied period, monthly air temperature between May and September was higher than $20^{\circ} \mathrm{C}$ with a maximum value in July. The changing trend of air temperature from 2011 to 2018 was not obvious. Most of the heaviest precipitation was concentrated in June, and the maximal monthly precipitation of 2015 and 2016 were $711 \mathrm{~mm}$ and $607 \mathrm{~mm}$, respectively. The increasing trend for precipitation emerged in September from 2011 to 2018.

Wind speeds declined in May, June, July and September from 2011 to 2018 (Fig. 2c). And monthly wind speed was below $3.1 \mathrm{~m} / \mathrm{s}$ during the whole studied period. The $P_{C U W D}$ exhibited a decline trend in May and June from 2011 to 2018 (Fig. 2d). The maximum $P_{C U W D}$ concentrated in summer. Especially, the $P_{C U W D}$ were above $48 \%$ in August 2016 and July 2017.

\section{Monthly variations in nutrient, Chl-a and bloom area}

TN showed a decreasing trend in May and June from 2011 to 2018 (Fig. 3a). The peak values of TP mainly appeared in August, which varied from 0.062 to $0.144 \mathrm{mg} / \mathrm{L}$. TP showed increasing trends in May and July. On the whole, TP raised from 2011 to 2018 (Fig. 3b). 

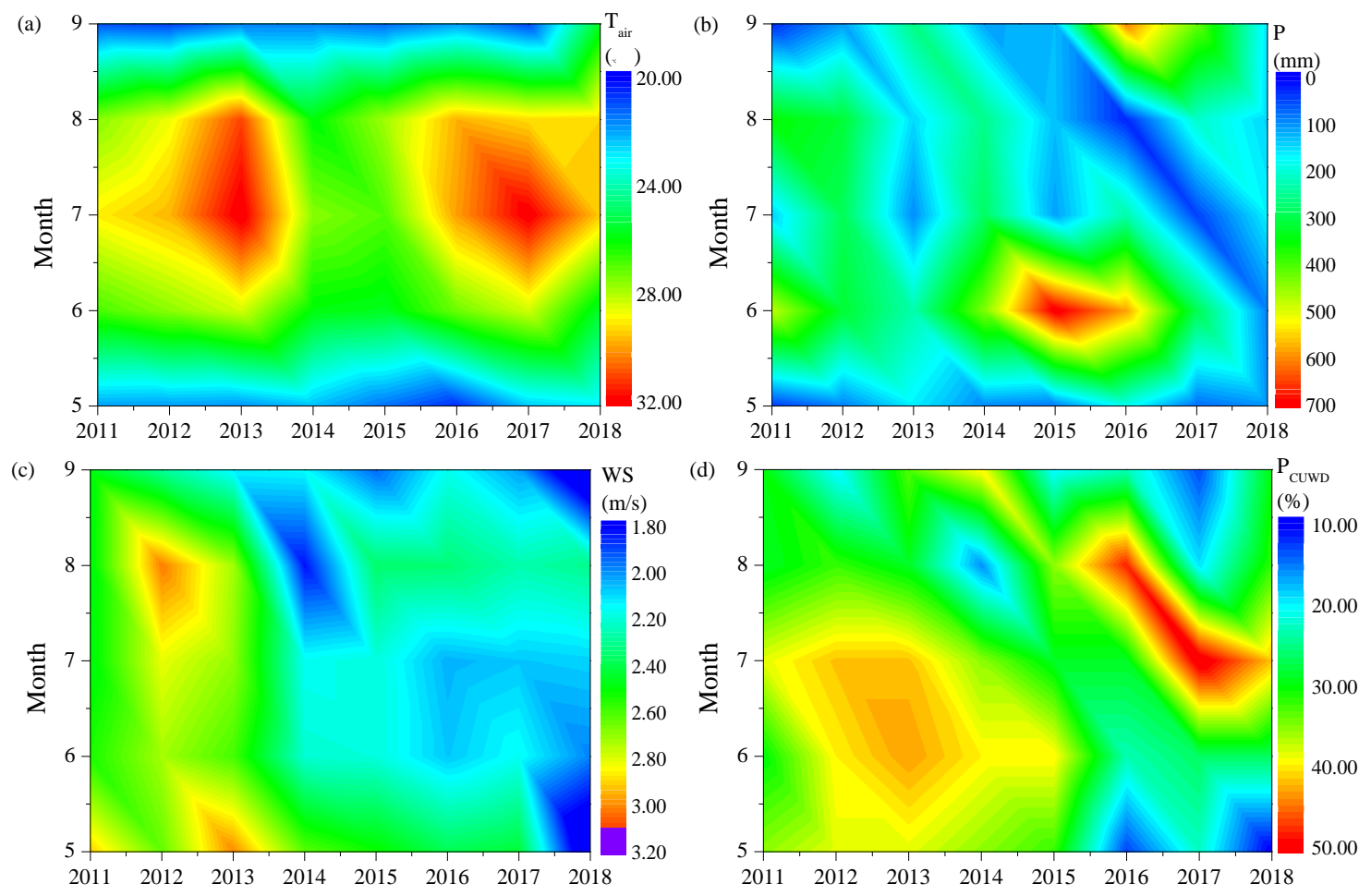

Figure 2. The temporal variations of (a) air temperature $\left(T_{\text {air }}\right),(b)$ precipitation $(P),(c)$ wind speed $(W S)$ and $(d)$ the month proportion of consecutive unidirectional winds days $\left(P_{C U W D}\right)$ between May and September from 2011 to 2018
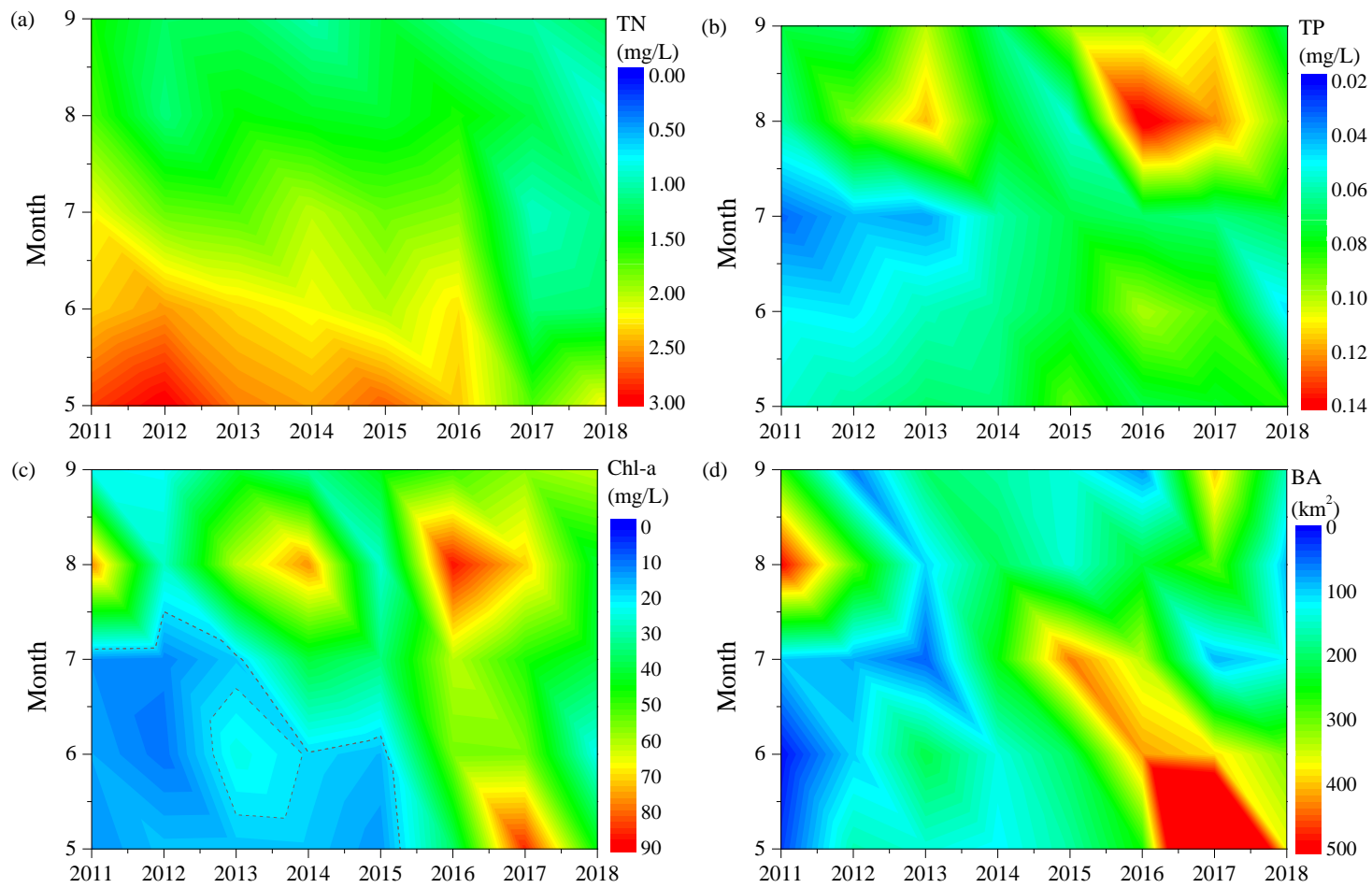

Figure 3. The temporal variations of (a) total nitrogen (TN), (b) total phosphorus (TP), (c) chlorophyll a (Chl-a) and (d) bloom area (BA) between May and September from 2011 to 2018 
Generally, the Chl-a concentration reached the maximum in August. In some cases, the Chl-a concentration reached $20 \mu \mathrm{g} / \mathrm{L}$, which was necessary for the formation of water bloom ahead of time, such as in May and June of 2016 and May 2017 with the highest Chl-a concentration reaching $86.2 \mu \mathrm{g} / \mathrm{L}$ (Fig. 3c). The increasing trends of Chl-a concentrations were found in May, July and September from 2011 to 2018. Unlike the temporal distribution of Chl-a concentration, the maximum bloom area is more random in temporal distribution. This means the bloom area may not reach the largest area when Chl-a concentration is the highest value (Fig. $3 c, d$ ). The bloom area showed increasing trends in May and June and decreasing trends in Aug and September during the studied period.

\section{Principle component analysis}

The results of KMO and significant Bartlett's test were 0.574 and 0.000, respectively, which demonstrated the validity of PCA approach. The PCA results showed (Table 1) that three eigenvalues were higher than one and the tree components explained $72.201 \%$ of the total variance of the selected environmental parameters. PC1, PC2, and PC3 contributed $37.223 \%, 20.383 \%$ and $14.595 \%$ to the total variance, respectively. PCA 1 was mainly positively related to wind speed, $P_{C U W D}$, and TN, and negatively related to TP and Chl-a. PC2 and PC3 were mainly correlated with air temperature and precipitation, respectively.

\section{Relationship between bloom area and environmental factors}

As shown in Table 2, the Chl-a concentration was significantly negatively correlated with wind speed $(\mathrm{P}<0.01), P_{C U W D}(\mathrm{P}<0.05)$ and $\mathrm{TN}(\mathrm{P}<0.01)$ and positively correlated with TP $(\mathrm{P}<0.01)$. There was no significant correlation between Chl-a concentration and air temperature. $P_{C U W D}$ and Chl-a concentration were the significant negative $(\mathrm{P}<0.01)$ and positive $(\mathrm{P}<0.01)$ factors affecting bloom area, respectively.

\section{Discussion}

Previous studies have confirmed that the formation of a surface water bloom is determine by two precondition, i.e. sufficient biomass of buoyant cyanobacteria and weak hydrodynamics (Paerl and Otten, 2013; Reynolds, 2006). Wu et al. (2015) found that the decline of wind speed had significantly promoted the extension of bloom area from 2000 to 2011. However, our results showed that the monthly bloom area between May to September from 2011 to 2018 was positively correlated with Chl-a concentration $(\mathrm{P}<0.01)$, but not with wind speed (Table 2). Microcystis, one of cyanobacteria species, is the dominant algae with biovolume accounting for $>95 \%$ from May to September in Lake Taihu (Chen et al., 2003; Otten and Paerl, 2011). Hence, Chl-a concentration was often used to represent Microcystis biomass in the previous field researches (Ding et al., 2012; Wu et al., 2013; Zhu et al., 2014a). Qin et al. (2015) defined Chl-a concentration above $20 \mu \mathrm{g} / \mathrm{L}$ as the visible surface cyanobacterial bloom in Taihu Lake. Our results indicated that most of Chl-a concentrations were higher than $20 \mu \mathrm{g} / \mathrm{L}$ between May and September during the studied period (Fig. 3c). Such a large amount of Microcystis float up and aggregate on water surface, which is enough to meet the biomass for the bloom formation. Cao et al. (2006) reported that the critical wind speed for bloom formation in Lake Taihu is $3.1 \mathrm{~m} / \mathrm{s}$. Wu et al. (2015) determined that 
the annual mean wind speed noticeably declined from 2000 to 2011 and ranged from 3.10 to $3.68 \mathrm{~m} / \mathrm{s}$. Although wind speed in our study decreased in May, June and July, the wind speeds of all months during the whole studied period were below the $3.1 \mathrm{~m} / \mathrm{s}$ (Fig. 2c). According to the above results, we can infer that no matter what the wind speed changes from 2011 to 2018, Microcystis in our studied months can overcome the wind-induced turbulence and rise to the water surface to form a bloom. Therefore, the correlation between wind speed and bloom area is not significant between May and September from 2011 to 2018.

Table 1. Total variance explained by the principle components during the bloom between May to September from 2011 to 2018 and the component matrix of different variables

\begin{tabular}{c|c|c|c}
\hline & PC1 & PC2 & PC3 \\
\hline Air temperature & 0.124 & 0.910 & 0.018 \\
Precipitation & -0.116 & 0.127 & 0.955 \\
Wind speed & 0.713 & 0.071 & -0.193 \\
$P_{C U W D}$ & 0.663 & 0.561 & -0.089 \\
Total nitrogen & 0.643 & -0.456 & 0.050 \\
Total phosphorus & -0.725 & 0.051 & -0.160 \\
Chlorophyll a & -0.830 & 0.229 & -0.190 \\
Eigenvalues & 2.606 & 1.427 & 1.022 \\
\% of Variance & 37.223 & 20.383 & 14.595 \\
Cumulative \% & 37.223 & 57.606 & 72.201 \\
\hline
\end{tabular}

$P_{C U W D}$ : monthly proportion of consecutive unidirectional winds days

Table 2. Pearson correlation coefficients between the monthly bloom area and environmental factors

\begin{tabular}{c|c|c|c|c|c|c|c|c}
\hline & $\mathbf{T}_{\text {air }}$ & $\mathbf{P}$ & $\mathbf{W S}$ & $\boldsymbol{P}_{\boldsymbol{C U W D}}$ & $\mathbf{T N}$ & $\mathbf{T P}$ & Chl-a & BA \\
\hline $\mathrm{T}_{\text {air }}$ & 1 & & & & & & & \\
$\mathrm{P}$ & 0.091 & 1 & & & & & & \\
$\mathrm{WS}$ & 0.133 & -0.120 & 1 & & & & & \\
$P_{C U W D}$ & $0.442^{* *}$ & -0.071 & $0.429 * *$ & 1 & & & & \\
$\mathrm{TN}$ & -0.208 & -0.042 & $0.434 * *$ & 0.164 & 1 & & & \\
$\mathrm{TP}$ & -0.084 & 0.063 & -0.227 & $-0.355^{*}$ & $-0.353^{*}$ & 1 & & \\
Chl-a & 0.128 & -0.009 & $-0.466^{* *}$ & $-0.401^{*}$ & $-0.456^{* *}$ & $0.630^{* *}$ & 1 & \\
BA & -0.094 & 0.019 & -0.213 & $-0.448^{* *}$ & -0.078 & 0.228 & $0.571^{* *}$ & 1 \\
\hline
\end{tabular}

$\mathrm{T}_{\text {air: }}$ air temperature; P: precipitation; WS: wind speed; $P_{C U W D}$ : monthly proportion of consecutive unidirectional winds days; TN: total nitrogen; TP: total phosphorus; Chl-a: chlorophyll a; BA: bloom area. $* * \mathrm{P}<0.01 ; * \mathrm{P}<0.05$

Interestingly, wind direction, another important indicator of wind speed, significantly affects the bloom area in this study. Our results illustrated a negative relationship between the bloom area and $P_{C U W D}(\mathrm{P}<0.05$, Table 2$)$. In order to better understand the influence of wind direction on bloom area, two typical months were selected, i.e. August 2016 and May 2017. The two months showed a big difference in bloom areas but very similar conditions of wind speeds and Chl-a concentrations. Specifically, the 
monthly bloom area was $231 \mathrm{~km}^{2}$ in Aug 2016 and $917 \mathrm{~km}^{2}$ in May 2017, the monthly mean wind speed was $2.35 \mathrm{~m} / \mathrm{s}$ in Aug 2016 and $2.44 \mathrm{~m} / \mathrm{s}$ in May 2017, and the Chl-a concentration was $88.1 \mu \mathrm{g} / \mathrm{L}$ in Aug 2016 and $86.2 \mu \mathrm{g} / \mathrm{L}$ in May 2017 (Fig. 3).

The structures of the lake currents are determined by in-out flows and wind. However, the horizontal migration of Microcystis is mainly induced by the surface current since Microcystis mainly concentrated on the water surface. Wu et al. (2018) indicated that surface current of Lake Taihu was driven by wind, and its entrainment could transfer energy further toward the lake bottom with increasing wind speed. In-out flows mainly contribute to lake currents when wind speed is $0 \mathrm{~m} / \mathrm{s}$, but the multiyear mean incidence of $0 \mathrm{~m} / \mathrm{s}$ in Lake Taihu is only $2.1 \%$ (Wu et al., 2013). Thus, impacts of in-out flows on water bloom in Lake Taihu was negligible. The wind field over Lake Taihu is composed of lake-land wind and East Asian monsoon (Wu et al., 2018). The hourly wind speed and direction are shown in Figure 4. Our results showed that wind speed had a diurnal periodic fluctuation, which was typically driven by the lake-land wind. However, the wind direction was generally more stable and did not appear obvious opposite situations between day and night. Lee et al. (2014) also indicated that lake-land breeze circulations were less prevalent in the Taihu lake basin than in lake basins in northern latitudes. Therefore, the calculated daily wind direction did not mask the information of hourly wind direction to some extent in this study.
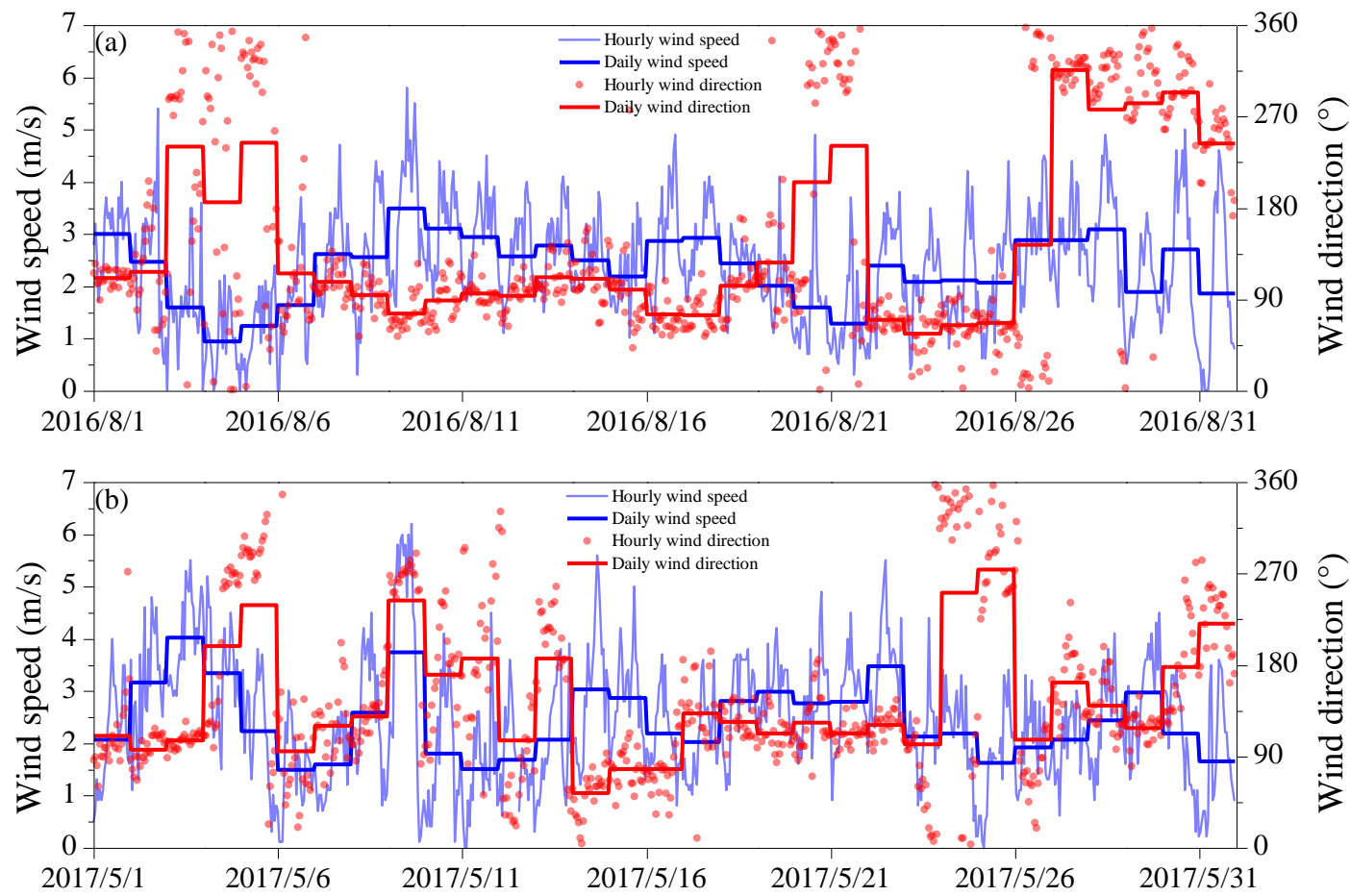

Figure 4. The hourly and daily wind speed and direction in (a) August 2016 and (b) May 2017

The proportion of hourly wind speed lower than $3.1 \mathrm{~m} / \mathrm{s}$ was $75.5 \%$ in August 2016 and $73.1 \%$ in May 2017 (Fig. 4). The low wind conditions in two months are favorable for the Microcystis to float on water surface. Moreover, the Chl-a concentration was both higher than $20 \mu \mathrm{g} / \mathrm{L}$ in the two months. These means the current Microcystis biomass can form water blooms only by vertical migration without horizontal drift 
under low wind speed $(3.1 \mathrm{~m} / \mathrm{s})$ (Cao et al., 2006; Qin et al., 2015). In previous field studies, it was observed that Microcystis patches were horizontally transported to downwind zone by wind-driven current under critical wind speed during summer (Bai et al., 2005; Deng et al., 2016; Moreno-Ostos et al., 2009). Meanwhile, positively buoyant Microcystis can resist downwelling to accumulate large biomass on the water surface of downwind end of the lake (Cyr, 2017). As shown in Figure 5, the bloom area was $625 \mathrm{~km}^{2}$ on $5^{\text {th }}$ August, but reduced to $236 \mathrm{~km}^{2}$ on $15^{\text {th }}$ August, and then continued to shrink to $62 \mathrm{~km}^{2} 25^{\text {th }}$ August under the influence of consecutive east winds in 2016. The maximum value of $C U W D$ (consecutive unidirectional winds days) in August 2016 was 14 days (Fig. 4). Compared with 2017, the bloom covered an area of $1309 \mathrm{~km}^{2}$ on $6^{\text {th }}$ May and maintained $1209 \mathrm{~km}^{2}$ on $16^{\text {th }}$ May under the effect of widely fluctuating wind directions. Then, after 7 days of unidirectional winds and 2 days of west wind, the bloom area was reduced to $649 \mathrm{~km}^{2}$ on $26^{\text {th }}$ May 2017, mostly accumulated in the eastern lake area (Fig. 5). The maximum value of CUWD in May 2017 was only 7 days (Fig. 4). Wu et al. (2010) found that, under the south wind, the Chl-a continuously increased in Meliang Bay and decreased in open water of Lake Taihu. We can infer from above that, under the effect of consecutive unidirectional winds, newly transported Microcystis patches from other zones will inevitably converge with the existing cyanobacterial patches in the downwind area of lake to form dense surface scum, resulting in the reduction of bloom area. Hence, the significantly different of bloom area in August 2016 and May 2017 was mainly affected by different wind direction variation patterns. The longer consecutive unidirectional winds days resulted in substantial reduction of bloom area, whereas unstable wind direction was beneficial to the stability of the bloom area.

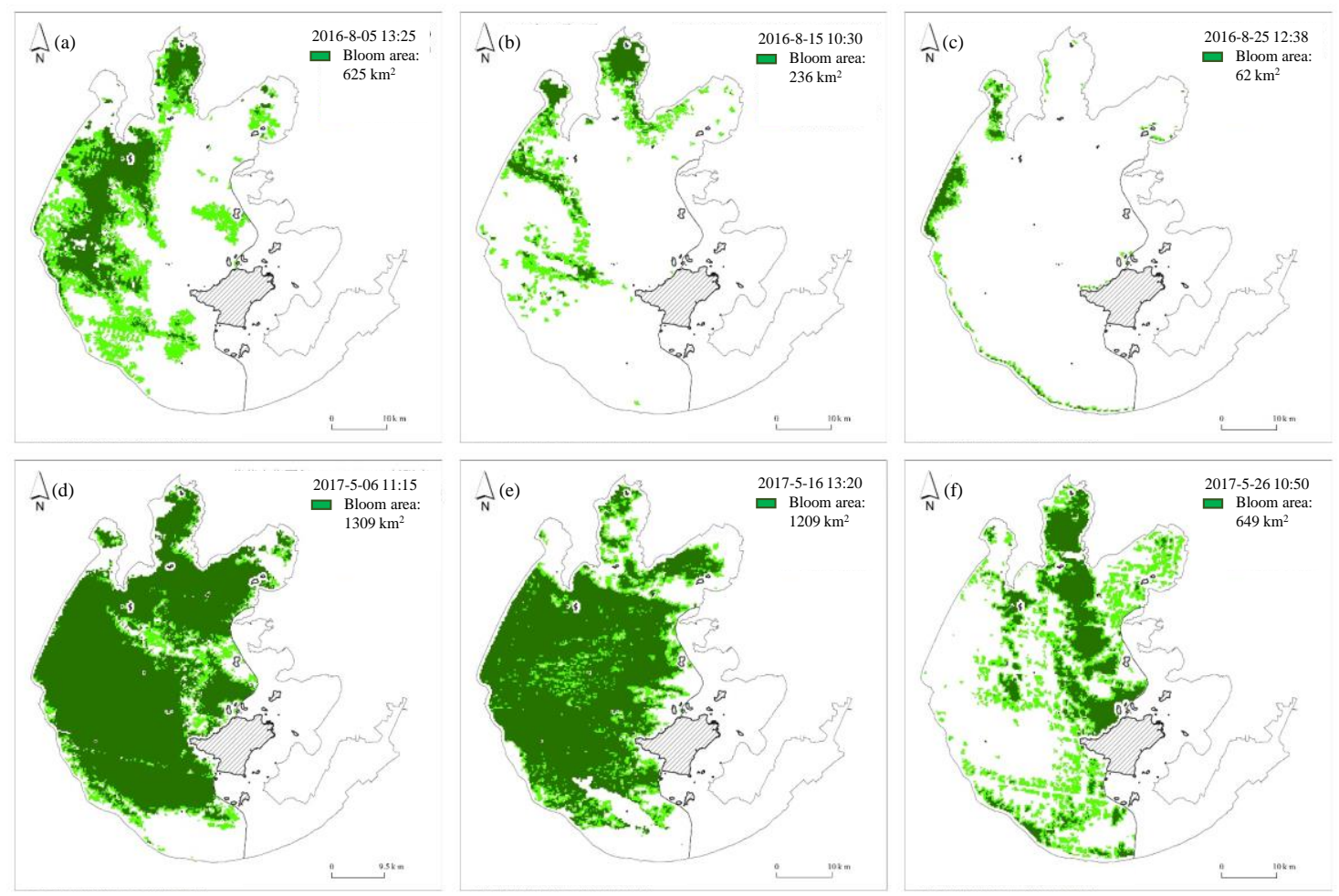

Figure 5. Bloom distribution Taihu on 3 days in ( $a, b$ and c) August 2016 and (d, e and f) May 2017, respectively 
After the 2007 water crisis in Wuxi, a series of comprehensive measures were conducted to control eutrophication and cyanobacterial bloom in Lake Taihu. The concentration of TN was effectively controlled and showed a noticeable decline in May and June, while the concentration of TP obviously rose in May and July from 2011 to 2018 (Fig. $3 a$ and $b$ ). Heavy precipitation above $600 \mathrm{~mm}$ both occurred in June 2015 and 2016 (Fig. 2b), and subsequent floods brought a large amount of nutrients input into Lake Taihu. As the floods receded, most phosphorous was gradually deposited into the sediment as particulate form while most nitrogen was discharged away Lake Taihu in dissolved form (Gouze et al., 2008; Zhu et al., 2018). Although decreased wind speed leads to reduce sediment resuspension, Microcystis easily float on water surface to obtain sufficient light for growth. The high aggregation of Microcystis on water surface, in turn, may promote phosphorus release from the sediment due to the low dissolved oxygen conditions near the bottom (Deng et al., 2018; Tang et al., 2015). These processes were indirectly supported by the positive relationship between Chl-a and TP $(\mathrm{P}<0.01)$ and the negative relationship between $\mathrm{Chl}-\mathrm{a}$ and wind speed $(\mathrm{P}<0.01$, Table 2). Some climate prediction studies suggested that the increase of air temperature and precipitation and decline of wind speed will continue in the Lake Taihu Basin in the future (IPCC, 2013; O'Reilly et al., 2015; Sun and Ding, 2010; Xu and Liu, 2012). Our result also showed the $P_{C U W D}$ decreased in May and June. Correspondingly, the bloom area showed an obvious increasing trend in May and June from 2011 to 2018. However, in July and August, the wind direction is steady and not conducive to the large-scale cyanobacterial bloom (Fig. $2 d$ and $4 d$; Table 1). Since the wind speed will continue to decrease in the Lake Taihu Basin in the future according to IPCC reports (IPCC, 2013), the lake-land wind with opposite wind directions between day and night will possibly dominate in the wind field in Lake Taihu. Thus, the future wind direction of Lake Taihu will become more unstable, which would be more conducive to the emergence of largescale cyanobacterial bloom in future. The large-scale cyanobacterial bloom would prevent the light penetration to inhibit the growth of green algae and diatoms below the water surface, thus reducing the phytoplankton biodiversity and aggravating eutrophication in lakes (Janatian et al., 2019; Shi et al., 2018; Xiao et al., 2018).

\section{Conclusion}

The obviously declined wind speeds between May and September, except for August, promoted the increases of TP and Chl-a concentrations from 2011 to 2018. During the whole studied period, the wind speeds were below the critical value for bloom formation and enough Microcystis biomass could aggregate into large-scale bloom area only by vertical floating. The decrease of wind speed has limited effects on the bloom areas. Randomly directed winds were conducive to maintain large-scale bloom area in May and June, while unidirectional winds could lead to shrink the bloom area in July and August. As the wind speed decreases in the future, the wind direction of Lake Taihu will become more unstable due to the influence of the lake-land wind. Future studies need to consider the impact of lake-land wind on the formation of largescale cyanobacterial bloom in Lake Taihu.

Acknowledgements. Acknowledgement for the data support from Lake-Watershed Science Data Center, National Earth System Science Data Sharing Infrastructure, National Science \& Technology Infrastructure of China (http://lake.geodata.cn). 


\section{REFERENCES}

[1] Bai, X., Hu, W., Hu, Z., Li, X. (2005): Importation of wind-driven drift of mat-like algae bloom into Meiliang Bay of Taihu Lake in 2004 summer. - Huanjing Kexue 26(6): 5760 .

[2] Cao, H., Kong, F., Luo, L., Shi, X., Yang, Z., Zhang, X., Tao, Y. (2006): Effects of wind and wind-induced waves on vertical phytoplankton distribution and surface blooms of Microcystis aeruginosa in Lake Taihu. - Journal of Freshwater Ecology 21(2): 231-238.

[3] Chen, Y., Qin, B., Teubner, K., Dokulil, M. T. (2003): Long-term dynamics of phytoplankton assemblages: Microcystis-domination in Lake Taihu, a large shallow lake in China. - Journal of Plankton Research 25(4): 445-453.

[4] Cyr, H. (2017): Winds and the distribution of nearshore phytoplankton in a stratified lake. - Water Res 122: 114-127.

[5] Deng, J., Qin, B., Paerl, H. W., Zhang, Y., Ma, J., Chen, Y. (2014): Earlier and warmer springs increase cyanobacterial (Microcystis spp.) blooms in subtropical Lake Taihu, China. - Freshwater Biology 59(5): 1076-1085.

[6] Deng, J., Chen, F., Liu, X., Peng, J., Hu, W. (2016): Horizontal migration of algal patches associated with cyanobacterial blooms in an eutrophic shallow lake. - Ecological Engineering 87: 185-193.

[7] Deng, J. M., Paerl, H. W., Qin, B. Q., Zhang, Y. L., Zhu, G. W., Jeppesen, E., Cai, Y. J., $\mathrm{Xu}$, H. (2018): Climatically-modulated decline in wind speed may strongly affect eutrophication in shallow lakes. - Science of the Total Environment 645: 1361-1370.

[8] Ding, Y., Qin, B., Zhu, G., Wu, T., Wang, Y., Luo, L. (2012): Effects of typhoon Morakot on a large shallow lake ecosystem, Lake Taihu, China. - Ecohydrology 5(6): 798-807.

[9] Feng, T., Wang, C., Wang, P., Qian, J., Wang, X. (2018): How physiological and physical processes contribute to the phenology of cyanobacterial blooms in large shallow lakes: a new Euler-Lagrangian coupled model. - Water Res 140: 34-43.

[10] Funari, E., Testai, E. (2008): Human health risk assessment related to cyanotoxins exposure. - Critical Reviews in Toxicology 38(2): 97-125.

[11] George, D., Edwards, R. (1976): The effect of wind on the distribution of chlorophyll a and crustacean plankton in a shallow eutrophic reservoir. - Journal of Applied Ecology 667-690.

[12] Gouze, E., Raimbault, P., Garcia, N., Bernard, G., Picon, P. (2008): Nutrient and suspended matter discharge by tributaries into the Berre Lagoon (France): the contribution of flood events to the matter budget. - Comptes Rendus Geoscience 340(4): 233-244.

[13] Han, T., Zhang, H., Hu, W., Deng, J., Li, Q., Zhu, G. (2015): Research on selfpurification capacity of Lake Taihu. - Environmental Science and Pollution Research 22(11): 8201-8215.

[14] Havens, K., Paerl, H., Phlips, E., Zhu, M., Beaver, J., Srifa, A. (2016): Extreme weather events and climate variability provide a lens to how shallow lakes may respond to climate change. - Water 8(6).

[15] Hecky, R., Kilham, P. (1988): Nutrient limitation of phytoplankton in freshwater and marine environments: a review of recent evidence on the effects of enrichment 1. Limnology and Oceanography 33(4part2): 796-822.

[16] IPCC (2013): Climate Change 2013. The Physical Science Basis. - In: Stocker, T. F., Qin, D., Plattner, G.-K., Tignor, M., Allen, S. K., Boschung, J., Nauels, A., Xia, Y., Bex, V., Midgley, P. M. (eds.) Working Group 464 I Contribution to the Fifth Assessment Report of the Intergovernmental Panel on Climate Change. Cambridge University Press, Cambridge, UK and New York. 
[17] Janatian, N., Olli, K., Cremona, F., Laas, A., Nõges, P. (2019): Atmospheric stilling offsets the benefits from reduced nutrient loading in a large shallow lake. - Limnology and Oceanography. https://doi.org/10.1002/lno.11342.

[18] Jeppesen, E., Meerhoff, M., Davidson, T. A., Trolle, D., Sondergaard, M., Lauridsen, T. L., Beklioglu, M., Brucet, S., Volta, P., Gonzalez-Bergonzoni, I., Nielsen, A. (2014): Climate change impacts on lakes: an integrated ecological perspective based on a multifaceted approach, with special focus on shallow lakes. - Journal of Limnology 73: 88111.

[19] Lee, X., Liu, S. D., Xiao, W., Wang, W., Gao, Z. Q., Cao, C., Hu, C., Hu, Z. H., Shen, S. H., Wang, Y. W., Wen, X. F., Xiao, Q. T., Xu, J. P., Yang, J. B., Zhang, M. (2014): The Taihu Eddy flux network an observational program on energy, water, and greenhouse gas fluxes of a large freshwater lake. - Bulletin of the American Meteorological Society 95(10): 1583-1594.

[20] Li, M., Zhu, W., Dai, X., Xiao, M., Appiah-Sefah, G., Nkrumah, P. N. (2014): Sizedependent growth of Microcystis colonies in a shallow, hypertrophic lake: use of the RNA-to-total organic carbon ratio. - Aquatic Ecology 48(2): 207-217.

[21] Li, Q., Hu, W., Zhai, S. (2016): Integrative indicator for assessing the alert levels of algal bloom in lakes: Lake Taihu as a case study. - Environmental Management 57(1): 237250.

[22] Ma, X., Wang, Y., Feng, S., Wang, S. (2015): Vertical migration patterns of different phytoplankton species during a summer bloom in Dianchi Lake, China. - Environmental Earth Sciences 74(5): 3805-3814.

[23] McVicar, T. R., Roderick, M. L., Donohue, R. J., Li, L. T., Van Niel, T. G., Thomas, A., Grieser, J., Jhajharia, D., Himri, Y., Mahowald, N. M., Mescherskaya, A. V., Kruger, A. C., Rehman, S., Dinpashoh, Y. (2012): Global review and synthesis of trends in observed terrestrial near-surface wind speeds: implications for evaporation. - Journal of Hydrology 416: 182-205.

[24] Michalak, A. M., Anderson, E. J., Beletsky, D., Boland, S., Bosch, N. S., Bridgeman, T. B., Chaffin, J. D., Cho, K., Confesor, R., Daloglu, I., DePinto, J. V., Evans, M. A., Fahnenstiel, G. L., He, L., Ho, J. C., Jenkins, L., Johengen, T. H., Kuo, K. C., LaPorte, E., Liu, X., McWilliams, M. R., Moore, M. R., Posselt, D. J., Richards, R. P., Scavia, D., Steiner, A. L., Verhamme, E., Wright, D. M., Zagorski, M. A. (2013): Record-setting algal bloom in Lake Erie caused by agricultural and meteorological trends consistent with expected future conditions. - Proceedings of the National Academy of Sciences 110(16): 6448-6452.

[25] Moreno-Ostos, E., Cruz-Pizarro, L., Basanta, A., George, D. G. (2008): The influence of wind-induced mixing on the vertical distribution of buoyant and sinking phytoplankton species. - Aquatic Ecology 43(2): 271-284.

[26] Moreno-Ostos, E., Cruz-Pizarro, L., Basanta, A., George, D. G. (2009): Spatial heterogeneity of cyanobacteria and diatoms in a thermally stratified canyon-shaped reservoir. - International Review of Hydrobiology 94(3): 245-257.

[27] O’Reilly, C. M., Sharma, S., Gray, D. K., Hampton, S. E., Read, J. S., Rowley, R. J., Schneider, P., Lenters, J. D., McIntyre, P. B., Kraemer, B. M., Weyhenmeyer, G. A., Straile, D., Dong, B., Adrian, R., Allan, M. G., Anneville, O., Arvola, L., Austin, J., Bailey, J. L., Baron, J. S., Brookes, J. D., de Eyto, E., Dokulil, M. T., Hamilton, D. P., Havens, K., Hetherington, A. L., Higgins, S. N., Hook, S., Izmest'eva, L. R., Joehnk, K. D., Kangur, K., Kasprzak, P., Kumagai, M., Kuusisto, E., Leshkevich, G., Livingstone, D. M., MacIntyre, S., May, L., Melack, J. M., Mueller-Navarra, D. C., Naumenko, M., Noges, P., Noges, T., North, R. P., Plisnier, P.-D., Rigosi, A., Rimmer, A., Rogora, M., Rudstam, L. G., Rusak, J. A., Salmaso, N., Samal, N. R., Schindler, D. E., Schladow, S. G., Schmid, M., Schmidt, S. R., Silow, E., Soylu, M. E., Teubner, K., Verburg, P., Voutilainen, A., Watkinson, A., Williamson, C. E., Zhang, G. (2015b): Rapid and highly 
variable warming of lake surface waters around the globe. - Geophysical Research Letters 42(24): 10773-10781.

[28] Otten, T. G., Paerl, H. W. (2011): Phylogenetic inference of colony isolates comprising seasonal Microcystis blooms in Lake Taihu, China. - Microb Ecol 62(4): 907-918.

[29] Paerl, H. W., Otten, T. G. (2013): Harmful cyanobacterial blooms: causes, consequences, and controls. - Microb Ecol 65(4): 995-1010.

[30] Qin, B., Zhu, G., Gao, G., Zhang, Y., Li, W., Paerl, H. W., Carmichael, W. W. (2010): A drinking water crisis in Lake Taihu, China: linkage to climatic variability and lake management. - Environmental Management 45(1): 105-112.

[31] Qin, B., Li, W., Zhu, G., Zhang, Y., Wu, T., Gao, G. (2015): Cyanobacterial bloom management through integrated monitoring and forecasting in large shallow eutrophic Lake Taihu (China). - Journal of Hazardous Materials 287: 356-363.

[32] Reichwaldt, E. S., Ghadouani, A. (2012): Effects of rainfall patterns on toxic cyanobacterial blooms in a changing climate: between simplistic scenarios and complex dynamics. - Water Res 46(5): 1372-1393.

[33] Reynolds, C. S. (2006): The Ecology of Phytoplankton. - Cambridge University Press, Cambridge.

[34] Shi, K., Zhang, Y., Zhu, G., Qin, B., Pan, D. (2018): Deteriorating water clarity in shallow waters: evidence from long term MODIS and in-situ observations. - International Journal of Applied Earth Observation and Geoinformation 68: 287-297.

[35] Shi, K., Zhang, Y., Zhang, Y., Li, N., Qin, B., Zhu, G., Zhou, Y. (2019): Phenology of phytoplankton blooms in a trophic lake observed from long-term MODIS data. Environmental Science \& Technology 53(5): 2324-2331.

[36] Sun, Y., Ding, Y. (2010): A projection of future changes in summer precipitation and monsoon in East Asia. - Science China Earth Sciences 53(2): 284-300.

[37] Tang, C., Li, Y., Jiang, P., Yu, Z., Acharya, K. (2015): A coupled modeling approach to predict water quality in Lake Taihu, China: linkage to climate change projections. Journal of Freshwater Ecology 30(1): 59-73.

[38] Wang, H., Zhang, Z., Liang, D., du, H., Pang, Y., Hu, K., Wang, J. (2016): Separation of wind's influence on harmful cyanobacterial blooms. - Water Res 98: 280-292.

[39] Wu, T., Qin, B., Zhu, G., Luo, L., Ding, Y., Bian, G. (2013): Dynamics of cyanobacterial bloom formation during short-term hydrodynamic fluctuation in a large shallow, eutrophic, and wind-exposed Lake Taihu, China. - Environmental Science and Pollution Research 20(12): 8546-8556.

[40] Wu, T., Qin, B., Brookes, J. D., Shi, K., Zhu, G., Zhu, M., Yan, W., Wang, Z. (2015): The influence of changes in wind patterns on the areal extension of surface cyanobacterial blooms in a large shallow lake in China. - Science of The Total Environment 518-519: 24-30.

[41] Wu, T. F., Qin, B. Q., Ding, W. H., Zhu, G. W., Zhang, Y. L., Gao, G., Xu, H., Li, W., Dong, B. L., Luo, L. C. (2018): Field observation of different wind-induced basin-scale current field dynamics in a large, polymictic, eutrophic lake. - Journal of Geophysical Research-Oceans 123(9): 6945-6961.

[42] Wu, X., Kong, F., Chen, Y., Qian, X., Zhang, L., Yu, Y., Zhang, M., Xing, P. (2010): Horizontal distribution and transport processes of bloom-forming Microcystis in a large shallow lake (Taihu, China). - Limnologica - Ecology and Management of Inland Waters 40(1): 8-15.

[43] Xiao, M., Li, M., Reynolds, C. S. (2018): Colony formation in the cyanobacterium Microcystis. - Biological Reviews 93(3): 1399-1420.

[44] Xu, Z., Liu, L. (2012): Detection of climate change and projection of future climate change scenarios in Taihu Lake Basin. - Advances in Science and Technology of Water Resources 32(1): 1-7. 
[45] Zhang, X., Chen, C., Lin, P., Hou, A., Niu, Z., Wang, J. (2011): Emergency drinking water treatment during source water pollution accidents in China: origin analysis, framework and technologies. - Environmental Science \& Technology 45(1): 161-167.

[46] Zhu, M., Paerl, H. W., Zhu, G., Wu, T., Li, W., Shi, K., Zhao, L., Zhang, Y., Qin, B., Caruso, A. M. (2014a): The role of tropical cyclones in stimulating cyanobacterial (Microcystis spp.) blooms in hypertrophic Lake Taihu, China. - Harmful Algae 39: 310321.

[47] Zhu, W., Li, M., Luo, Y., Dai, X., Guo, L., Xiao, M., Huang, J., Tan, X. (2014b): Vertical distribution of Microcystis colony size in Lake Taihu: its role in algal blooms. - Journal of Great Lakes Research 40(4): 949-955.

[48] Zhu, W., Tan, Y., Wang, R., Feng, G., Chen, H., Liu, Y., Li, M. (2018): The trend of water quality variation and analysis in typical area of Lake Taihu, 2010-2017. - Journal of Lake Sciences 30(2): 296-305. 